\title{
Hydro-mechanical effects of seismic events in crystalline rock barriers
}

\author{
Dominik Kern ${ }^{1}$, Fabien Magri ${ }^{2,3}$, Victor I. Malkovsky ${ }^{4}$, and Thomas Nagel $^{1}$ \\ ${ }^{1}$ Institute for Geotechnics, TU Bergakademie Freiberg, Freiberg, Germany \\ ${ }^{2}$ Division Task-related Research, Federal Office for the Safety of Nuclear Waste Management, Berlin, Germany \\ ${ }^{3}$ Institute of Geological Sciences, Freie Universität Berlin, Berlin, Germany \\ ${ }^{4}$ Institute of Geology of Ore Deposits and Petrography and Mineralogy and Geochemistry, \\ Russian Academy of Sciences, Moscow, Russia \\ Correspondence: Dominik Kern (dominik.kern1@ifgt.tu-freiberg.de)
}

Published: 10 November 2021

\begin{abstract}
Under ideal conditions, owing to its extremely low matrix permeability, crystalline rock can constitute a suitable hydro-geological barrier. Mechanically, its high strength and stiffness provide advantages when constructing a repository and for long-term stability. However, crystalline rock usually occurs in a fractured form, which can drastically alter hydromechanical (HM) barrier functions due to increased permeability and decreased strength. Seismic events have the potential to alter these HM properties by activating faults, increasing their transmissibility, creating new fractures or altering network connectivity (De Rubeis et al., 2010). Therefore, it is of high importance to build computational models to allow assessment of the HM effects of seismic events in a Deep Geologic Repository (DGR) in crystalline rock, as illustrated in Fig. 1. For this purpose, we consider a DGR in Russia (Yeniseysky site) for high-level waste in crystalline rock (Proterozoic and Archaean gneiss complexes) that is located close to a potentially seismically active area (Jobmann, 2016). Here, we present a coupled HM simulation, using OpenGeoSys (Kolditz et al., 2012), of a large-scale, three-dimensional finiteelement model of the Yeniseysky site to assess the consequences of seismically induced stress-field changes on the local stress field and the fluid flow. This research also provides an outlook of current model development geared towards a more detailed assessment of seismically induced hydro-mechanical processes in porous and fractured rocks.
\end{abstract}

Kurzfassung. Aufgrund seiner extrem geringen Matrixpermeabilität kann kristallines Gestein unter Idealbedingungen eine geeignete Barriere gegenüber Wasser darstellen. Unter mechanischen Gesichtspunkten bietet seine enorme Festigkeit und Steifigkeit Vorteile für die Konstruktion eines auch langfristig stabilen Endlagers. Allerdings tritt kristallines Gestein meist in gebrochener Form auf, was seine hydromechanische (HM) Barrierefunktion aufgrund der erhöhten Permeabilität und reduzierten Festigkeit enorm verändern kann. Durch seismische Ereignisse können diese HM-Eigenschaften verändert werden, wenn sie Verwerfungen aktivieren, deren Durchlässigkeit erhöhen, neue Brüche verursachen oder die Konnektivität im Netzwerk des Gesteins verändern (De Rubeis et al., 2010). Entscheidend ist daher, Computermodelle zu entwickeln, mit denen sich die HMEffekte von seismischen Ereignissen in einem geologischen Tiefenlager (Deep Geologic Repository, DGR) in kristallinem Gestein beurteilen lassen, so wie in Abb. 1 dargestellt. Um dies zu untersuchen, prüfen wir ein DGR in Russland (Jenissej Gebiet), das als Lager für hoch radioaktiven Abfall in kristallinem Gestein (proterozoische und archaische Gneise) dient und in dessen Nähe eine wahrscheinlich seismisch aktive Region liegt (Jobmann, 2016). Wir beschreiben hier unter Nutzung von OpenGeoSys (Kolditz et al., 2012) eine hydromechanisch gekoppelte Simulation eines großflächigen, dreidimensionalen Finite-Elemente-Modells des Jenissej Gebiets, um die Folgen von seismisch induzierten Änderungen des Spannungsfeldes für das lokale Spannungsfeld und den Flüssigkeitsstrom zu beurteilen. Unsere Forschung bietet auch einen Ausblick auf die derzeitige Entwicklung von Modellen hin zu einer detaillierteren Bewertung von seismisch verursachten hydromechanischen Prozessen in porösem und brüchigem Gestein. 

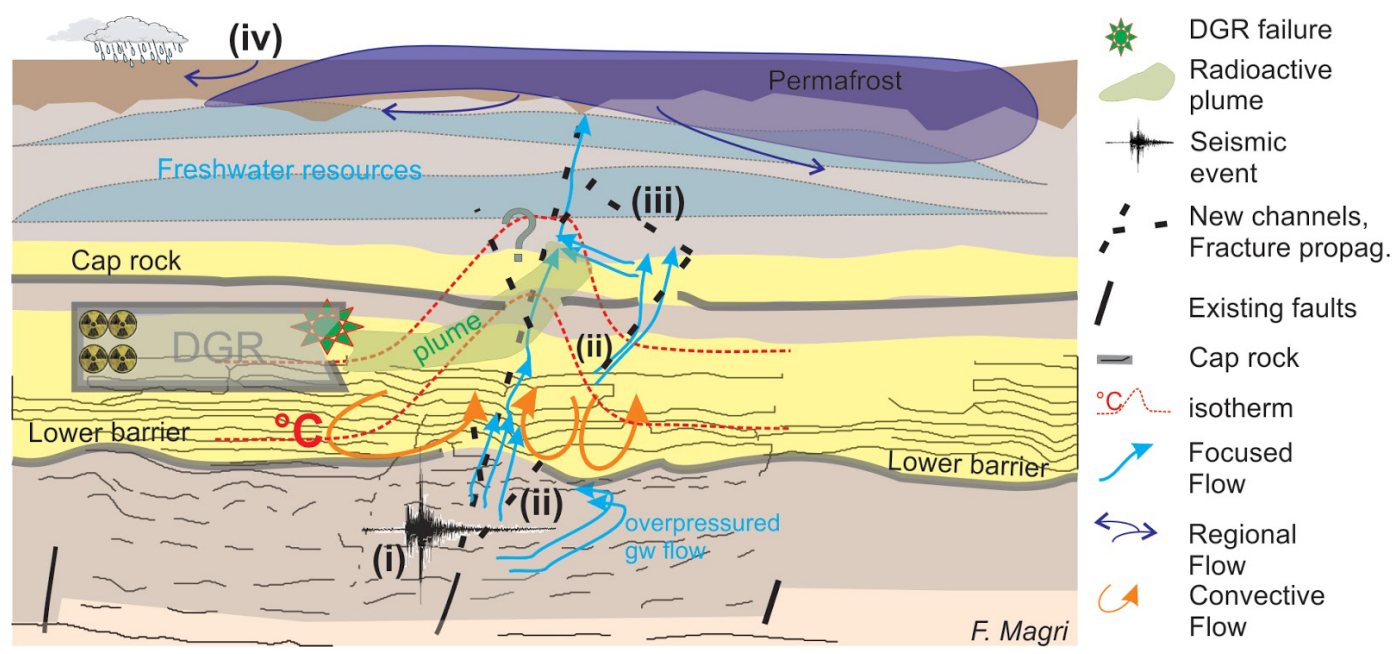

Figure 1. Most relevant events for the integrity of a DGR in crystalline rock. (i) Cap-rock failure due to seismic events, (ii) focused flow escapes from the aquifer, (iii) flow-induced fractures propagate generating a heterogeneous porosity-permeability field, (iv) changing climate/permafrost impacts (Magri et al., 2020).

Financial support. This research has been supported by the Deutsche Forschungsgemeinschaft (grant nos. NA1528/2-1 and MA4450/5-1) and the Russian Foundation for Basic Research.

\section{References}

De Rubeis, V., Czechowski, Z., and Teisseyre, R.: Synchronization and Triggering: from Fracture to Earthquake Processes, Springer, Berlin, Heidelberg, Germany, 2010.

Jobmann, M.: Site-specific evaluation of safety issues for high-level waste disposal in crystalline rocks. Final report, Tech. rep., DBE Technology GmbH, Peine, Germany, 2016.
Kolditz, O., Görke, U.-J., Shao, H., and Wang, W.: Thermo-hydromechanical-chemical processes in porous media: benchmarks and examples, vol. 86, Springer Science \& Business Media, Berlin, Heidelberg, Germany, 2012.

Magri, F., Nagel, T., Liebscher, A., and Malkovsky, V.: Impacts of changing conditions on far-field radionuclide evolution: background and goals of a newly funded DFG-RFBR project, EGU General Assembly 2020, Online, 4-8 May 2020, EGU202017712, https://doi.org/10.5194/egusphere-egu2020-17712, 2020. 